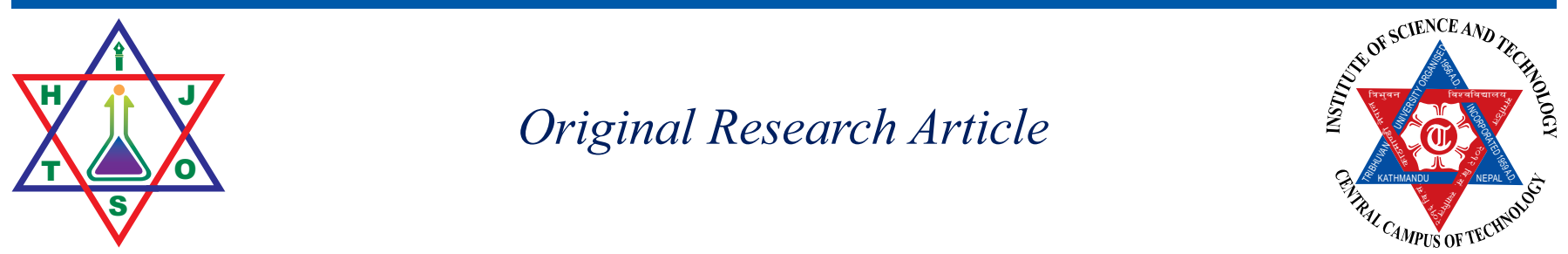

\title{
Effect of Adding Mashed Potato on Physiochemical and Sensorial Properties of
}

\author{
Masyaura \\ Geeta Bhattarai ${ }^{I^{*}}$, Sanjay Bhandari ${ }^{2}$ and Dambar Bahadur Khadka ${ }^{3}$ \\ ${ }^{1}$ Central Department of Food Technology, Tribhuvan University, Dharan, Nepal \\ ${ }^{2}$ Regional Food Technology and Quality Control Office (RFTQC), Biratnagar, Nepal \\ ${ }^{3}$ Central Campus of Technology, Tribhuvan University, Dharan, Nepal
}

*Corresponding Author: Geeta Bhattarai, Central Department of Food Technology, Tribhuvan University, Dharan, Nepal, E-mail:bhattarai_geeta10@yahoo.com

\begin{abstract}
:
Masyaura, an ethnic, fermented and dried, cone shaped, black or green gram product, is prepared by Nepalese people living in the Himalayas. Masyaura is especially prepared from split black gram (Phaseolus mungo) and Colocasia (Colocasia esculenta) or radish and ash gourd depending upon the availability of raw materials. The taste and texture are the fundamental characteristics of Masyaura. Breakage or loss of integrity after drying, during handling, packing and cooking are observed as acommon problems of Masyaura. In this study, effect of addition of mashed potato on physiochemical and sensory quality of Masyaura was studied. Masyaura prepared by using black gram and colocasia tuber in the ratio 2:1 with fermentation time of $2 \mathrm{~h}$ was taken as control. Black gram was partially replaced by different proportion of mashed potato $(6.25,12.5,18.75$ and 25 parts by weight) to study the effect on physiochemical and sensory quality of Masyaura. Rehydration ratio, bulk density and disintegration time of Masyaura varied from 2.60:1 to $3.45: 1,510$ to $654 \mathrm{~kg} / \mathrm{m}^{3}$ and 35.75 to 45.91 min respectively. Masyaura prepared by incorporating mashed potato had higher bulk density, longer disintegration time and lower rehydration ratio compared to control. Sensory evaluation showed that 18.75 parts mashed potato incorporated Masyaura had the best sensory quality of all the proportions studied. Incorporation of mashed potato in partial replacement of black gram could significantly improve the textural property of Masyaura.
\end{abstract}

Keywords: Masyaura, mashed potato, disintegration, rehydration, quality

\section{Introduction}

Maseura or Masyaura is an ethnic, fermented black or green gram product prepared by Nepalese people living in the Himalayas (Tamang, 2010). It is a cone-shaped hollow, brittle and friable product (Tamang and Kailasapathy, 2010). Masyaura is an important legumebased traditional food of Nepal. It is a product similar to north Indian Wari and south Indian Sandige. They are brittle and spongy textured dried balls of $2-5 \mathrm{~cm}$ in diameter (Dahal et al, 2005). Masyaura is especially prepared from split black gram (Phaseolus mungo) and Colocasia (Colocasia esculenta) or radish and ash gourd depending upon the availability of raw materials (Gajurel and Baidya, 1979; Karki, 1986). The dried balls are stored at ambient conditions. It is mixed with curry to make soup and served with rice as a side dish. Dried Masyaura has final moisture content of $8-10 \%$. It is cheap and rich source of protein $(18-20 \%$ on fresh weight), carbohydrates $(67-70 \%$ on fresh weight) and minerals (Dahal et al, 2003), and also known as meat for vegetarians (Gajurel and Baidya, 1979). The traditional method of Masyaura preparation from blackgram and Colocasia tuber is well documented (Dahal, 2005). Traditional foods like Masyaura based on available local resources are important components of the Nepalese diet as staples, adjuncts to staples, condiments and beverages (Dahal et al, 2005). The quality of Masyaura is not consistent due to variability of production process in different communities. Previous studies on Masyaura 
provides information regarding selection of best proportion of different pulses and vegetables for Masyaura preparation (Subba, 1985), quality of Masyaura prepared using pulses and vegetables (Lama, 1988), formulation of protein rich Masyaura with incorporation of soyabeans (Subedi, 1999), effect of fermentation time and temperature on quality of Masyaura (Deo, 2003) and fermentation and nutritional evaluation of Masyaura (Dahal, 2005). However, loss of Masyaura integrity after drying, during handling, packing and cooking have not been addressed so far. Hence, this study is carried out to assess the effect of incorporating mashed potato in Masyaura recipe on physicochemical (bulk density, rehydration ratio, disintegration time) and sensorial properties.

\section{Materials and Methods}

Black gram, colocasia tuber and potato were collected from local market of Dharan. Masyaura prepared using two parts of black gram and one part of colocasia tuber was used as a control. Black gram was partially replaced with mashed potato $6.25,12.5,18.75$ and 25 parts by weight) and studied for rehydration ratio, rehydration time, bulk density, disintegration time and sensory qualities. The parts variation of mashed potato for partial replacement of black gram was obtained from response surface methodology.

Mashed potato was prepared by boiling potato for 15 minutes followed by peeling and mashing manually before using in Masyaura recipe. Black gram was cleaned, soaked overnight in clean water, dehuled followed by we grinding prior to use in Masyaura preparation. Similarly clocasia tuber was washed, peeled, shredded followed by hot water blanching at 70 ${ }^{0} \mathrm{C}$ for $5 \mathrm{~min}$ and use for Masyaura. The detailed process used for Masyaura preparation is shown in Fig 1. Masyaura was prepared and rehydration ratio, rehydration time, bulk density, disintegration time and sensory qualities were studied.

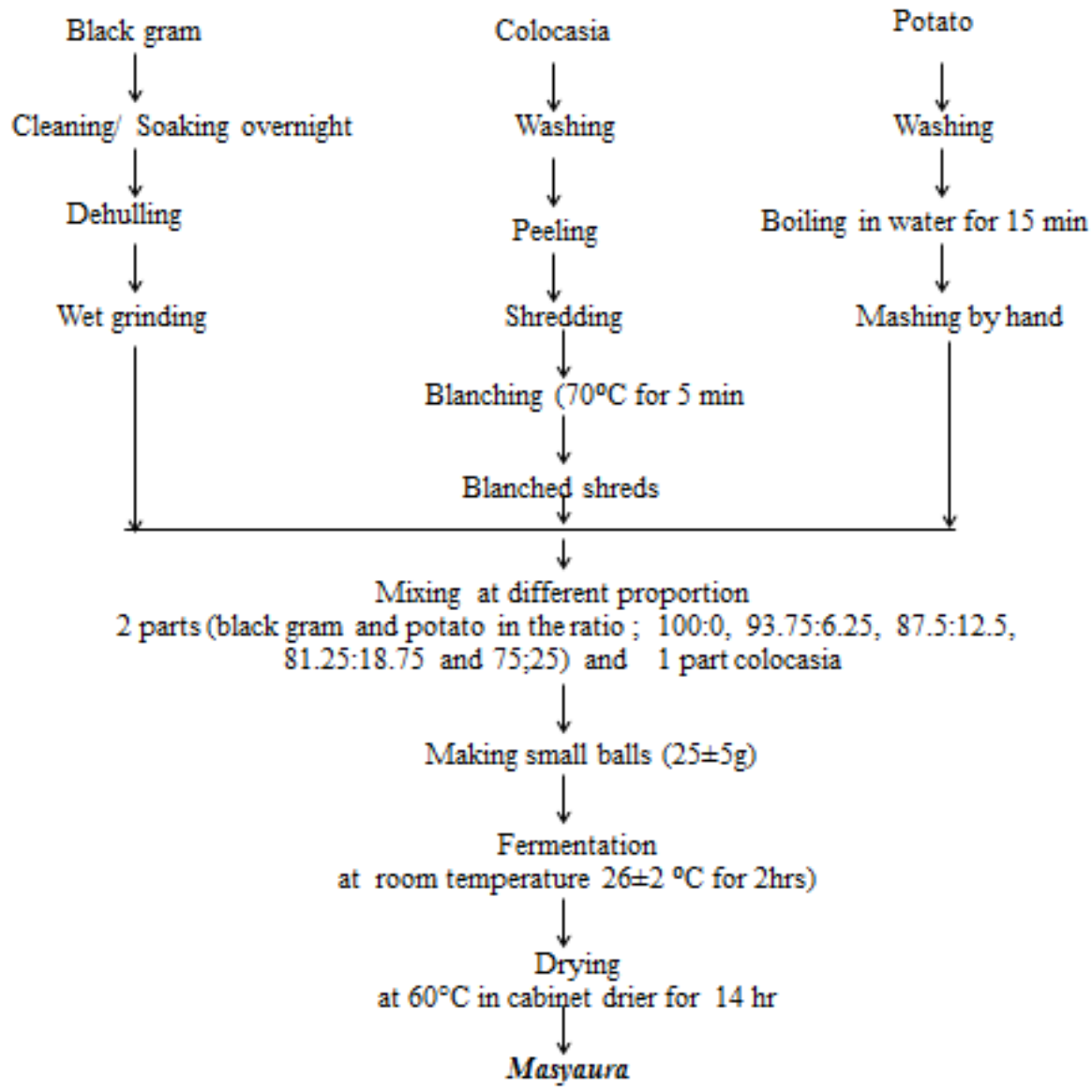

Fig 1. Flow chart for Masyaura preparation with slight modifation (Subba 1985) 


\section{Physical and Chemical Analysis \\ Determination of bulk density:}

Bulk density was determined by a volumetric replacement method using mustard seed as the replacement medium (Nepal Standard, 2037 BS). A special wooden box suitable for Masyaura was prepared and was used to measure the volume of Masyaura. Mustard seeds with more or less similar in size were used. The bulk density of Masyaura was calculated using the following formula:

$$
\rho_{s}=\frac{W s}{W m} \times \rho_{m}
$$

Where $\rho \mathrm{s}=$ bulk density of Masyaura $\left(\mathrm{kg} / \mathrm{m}^{3}\right)$; Ws $=$ weight of Masyaura; $\mathrm{Wm}=$ weight of mustard seeds with the same volume as that of the Masyaura $(\mathrm{g})$; and $\mathrm{\rho m}=$ bulk density of mustard seeds $\left(\mathrm{kg} / \mathrm{m}^{3}\right)$.

\section{Determination of disintegration time:}

Disintegration time (the time required for start of visual disintegration) of Masyaura was determined in boiling water.

Determination of rehydration time: The rehydration ratio was determined as described by Ranganna (2007).

\section{Proximate Analysis}

Moisture content by hot air oven method, protein content by micro-Kjeldahl method, fat by soxhlet extraction method and ash content were determined as described by Ranganna (2007).

\section{Sensory Analysis}

Sensory quality of the products were evaluated by 20 semi trained panelist comprising of faculties and research students of CCT, Dharan by using nine points hedonic rating test as suggested by Ranganna (2007). The samples were cooked in boiling water for $10 \mathrm{~min}$ and subjected for sensory analysis in terms of appearance/color, shape, smell, taste, texture and overall acceptance.

\section{Data Analysis}

The data were analyzed by one way ANOVA using IBMSPSS Statistics 20 and the means were compared by using Tukey HSD test.

\section{Results and Discussion}

Effects of mashed potato addition on the physical properties of Masyaura

Effects of mashed potato incorporation on bulk density, disintegration time and rehydration ratio of Masyaura was studied and the results are shown in Figs 2a, 2b \& 2c.

\section{Effect on bulk density:}

The bulk densities of Masyaura prepared by incorporating 0 (control), 6.25, 12.5, 18.75 and 25 parts of mashed potato were $509.92 \pm 4.66,510.01 \pm 3.79$, $552.70 \pm 9.40,617.04 \pm 9.30$ and $654.14 \pm 11.0 \mathrm{~kg} / \mathrm{m}^{3}$

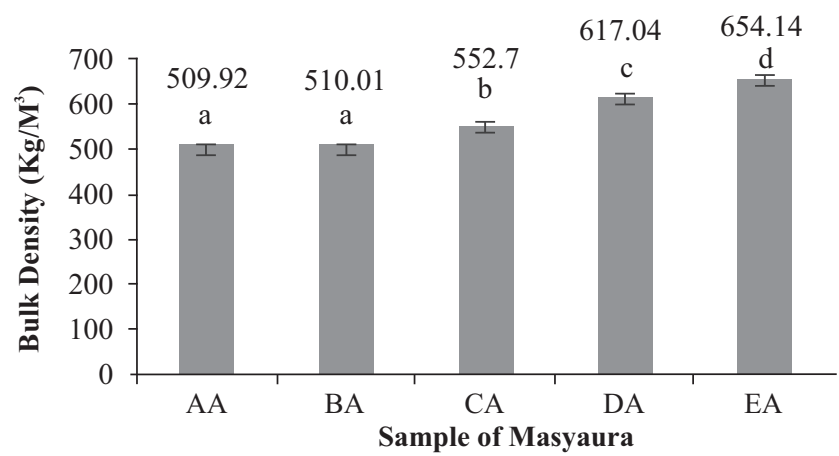

(a)

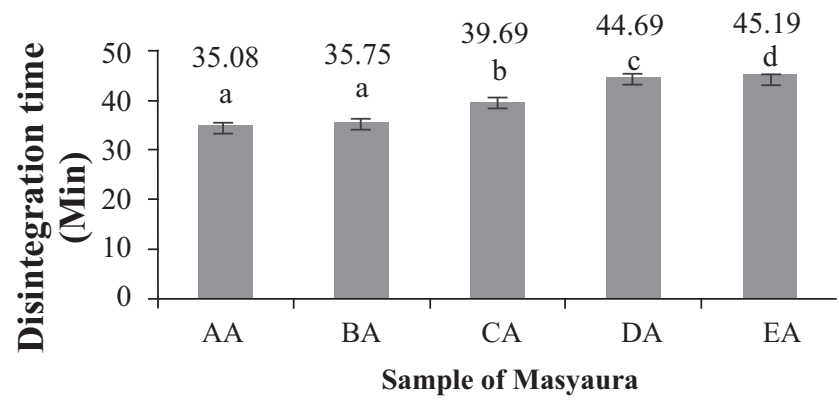

(b) 


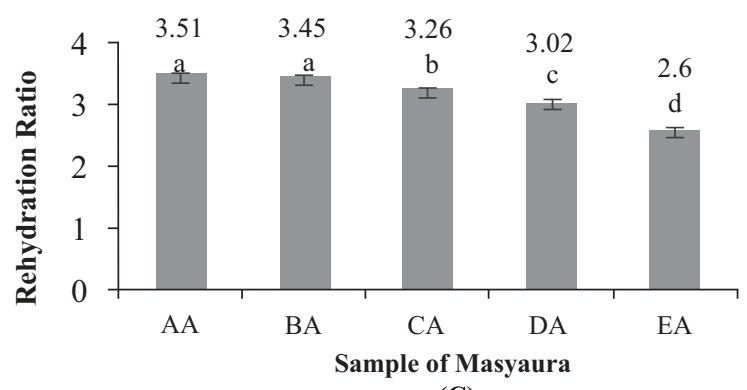

(C)

Fig 2. Effect of incorporation of mashed potato on a) bulk density, b) disintegration time and c) rehydration ratio of Masyaura

The values in the Figures are the mean of the triplicates \pm standard deviation. The similar alphabets above the bar diagram indicate not significant difference $(\mathrm{p}>0.05)$. AA, BA, CA, DA and EA denote Masyaura added with 0 (control), 6.25, 12.5, 18.75 and 25 parts mashed potato respectively.)

respectively (Fig. 2a). Statistical analysis revealed that addition of mashed potato had a significant effect $(p<0.05)$ on the bulk density of Masyaura. Tukey HSD test indicated the bulk densities of control and 6.25 parts mashed potato added Masyaura were not significantly different $(\mathrm{p}>0.05)$, while the values for other samples were significantly different from each other. From Fig.2a, it can be seen that increasing the level of mashed potato significantly increased the bulk density. Analogous results were also reported by Subedi (1999) for Masyaura prepared from black gram and soybean, but Dahal (2005) reported higher values than those obtained in this study. The bulk density of a material depends on the solid density and the geometry, size and surface properties of the individual particles (Fellows, 2000).

\section{Effect on disintegration time:}

The disintegration time of Masyaura prepared by adding 0 (control), 6.25, 12.5, 18.75 and 25 parts of mashed potato were $35.08 \pm 0.38,35.75 \pm 0.46,39.69 \pm$ $1.05,44.19 \pm 0.67$ and $45.91 \pm 0.22$ mins respectively (Fig. 2b). Statistical analysis showed that incorporation of mashed potato had significant effect on disintegration time of Masyaura $(p<0.05)$. Incorporation of mashed potato at the rate of 6.25 parts had no significant effect as compared to control. However, increasing levels of mashed potato up to 25 parts significantly increased disintegration time (Fig 2b). Potato flour has shown superior to increase cooking yield, hardness and water retention than other flour such as cassava sago, corn and

\section{$\square \mathrm{AA}$ 目BA 回CA $\mathrm{DDA}$ 田A}

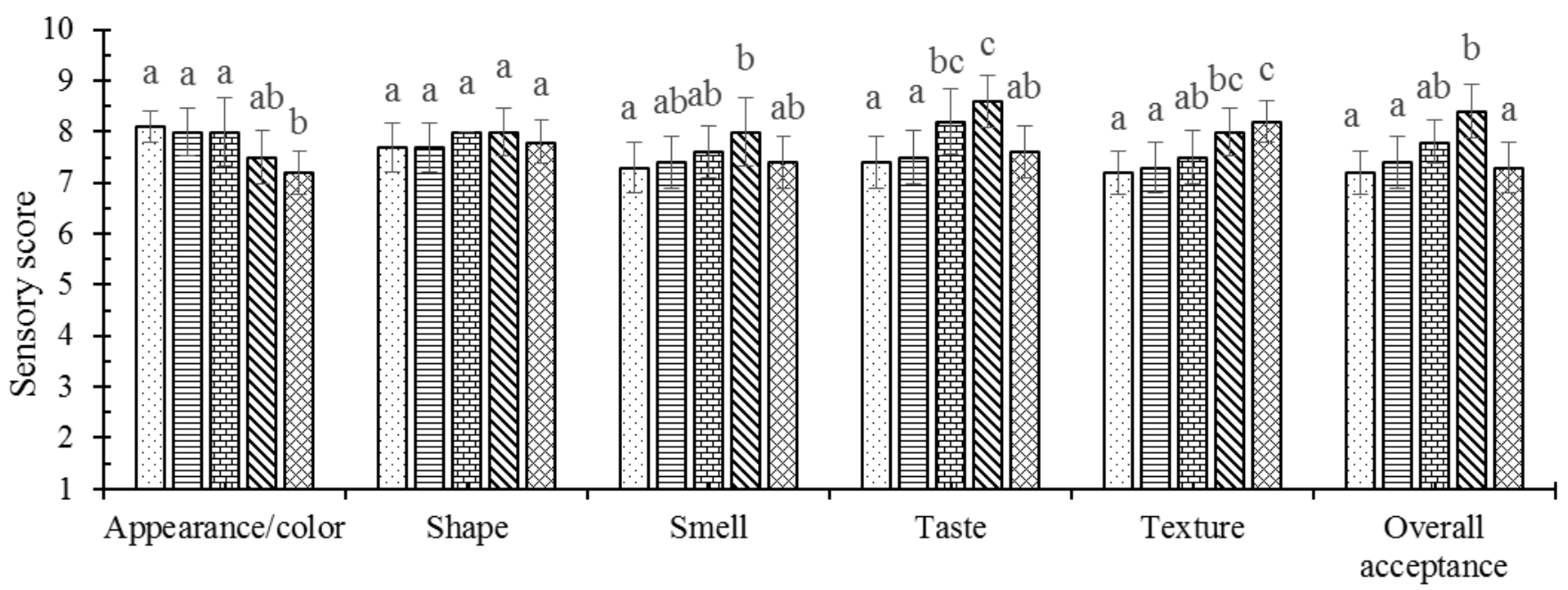

\section{Sensory parameter}

Fig 3. Effect of mashed potato incorporation on sensory quality of MasyauraThe similar alphabets above the bar diagram indicate not significant difference $(\mathrm{p}>0.05)$. AA, BA, CA, DA and EA denote Masyaura added with 0 (control), $6.25,12.5,18.75$ and 25 parts mashed potato, respectively. 
wheat (Ikhlas et al, 2011). It was also reported that heat induced gelatinization of the starch granule could bring changes on structure and arrangement of amylose and amylopectin responsible for good binding properties in tablet production (Moran, 1989; Schwartz and Zelinskie, 1978). In addition, hydrolyzed potato protein has also shown increased in the cooking yield by decreasing fracture in emulsion type sausage (Nieto et al, 2009).

\section{Effect on Rehydration Ratio}

The Rehydration ratio of Masyaura prepared by incorporating 0 (control), 6.25, 12.5, 18.75 and 25 parts of mashed potato were $3.51 \pm 0.017,3.45 \pm 0.019,3.26 \pm$ $0.025,3.02 \pm 0.085$ and $2.60 \pm 0.028$ respectively (Fig 2c). These values were in the similar range as explained by earlier studies (Deo, 2003; Subedi 1999). Statistical analysis revealed that addition of mashed potato had a significant effect $(p<0.05)$ on the rehydration ratio of Masyaura. In this study, incorporation of mashed potato at 6.25 parts showed no significant difference on rehydration ratio with control; however, further addition of mashed potato significantly decreased the rehydration ratio of Masyaura (Fig 2c). Heat reduces the degree of hydration of starch and the elasticity of cell walls, and coagulates proteins to reduce their water-holding capacity (Fellows, 2000). Rehydration of dried product is not reversible because of loss in cellular osmotic pressure, changes in cell membrane permeability, crystallization of polysaccharides and coagulation of cellular proteins (Rahman and Perera, 1999). Rehydration is maximized when cellular and structural disruption, such as shrinkage, is minimized. (Okoset al, 2006).

\section{Effect on sensory quality:}

The effect of mashed potato incorporation at different proportion in Masyaura on appearance, shape, smell, taste, texture and overall acceptance are presented in Fig. 3.

Masyaura with 18.75 parts incorporation of mashed potato obtained the highest mean score (8.4) for overall acceptance and was significantly different from control, 6.25 and 25 parts of mashed potato incorporated Masyaura. For appearance and colour, Masyaura with 18.75 parts mashed potato addition was not significantly different with control, $6.25,12.5$ parts but significantly difference with 25 parts mashed potato incorporated Masyaura. Mashed potato compared to potato powder have shown to increase the brightness in Masyaura like North Indian product; wari (Kaur and Aggarwal, 2016).
In fact, the perceptions of the color of the object represent the results from differences in the absorption of radiant energy at various wavelengths by the object (Lawless and Heymann, 2010). However, with respect to Masyaura, there is different perception regarding the preferred color. Subedi (1999) reported most of the panelists liked yellowish brown color, while Deo (2003) reported light brown color was preferred by the panelists.

Regarding smell, taste and texture, 18.75 part mashed potato incorporated Masyaura was found superior from sensory analysis as compared to other samples.

Both potato starch and protein can improve binding interaction with improve hardness and water binding capacity and also reduce the fracture formation (Ikhlas et al, 2011; Nieto et al, 2009 ) and can contribute the improved texture. When potato tubers are cooked, fatty acids degrade to produce aldehydes and ketones, which contribute to flavor (Jansky, 2010). Potato tubers have high levels of 5' ribonucleotides and liberated by enzymatic hydrolysis of RNA as tubers are heated during cooking. In fact, the products of interactions between amino acids and 5 ribonucleotides are considered to be mainly responsible for boiled potato flavor (Jansky, 2010).

\section{Effect on Rehydration time}

Rehydration time for Masyaura prepared by using mashed potato increased with increase in proportion of mashed potato (Fig. 4). The rate of rehydration was very faster till $10 \mathrm{~min}$ (i.e rehydration ratio 1.91-2.61) and then became slower (rehydration ratio ranges 2.2-2.9 in 20 min; 2.4-3.5 in 30 min soaking time) and almost constant after 40 min (Fig. 4).

Similar trend of rehydration patterns of Masyaura was also explained by Dahal (2005). During rehydration, absorption of water is faster at the beginning and thereafter slows down. This rapid moisture uptake is due to surface and capillary suction. Porosity, capillaries and cavities near the surface enhance the rehydration process, whereas the presence of trapped air bubbles is a major obstacle to the invasion of the fluid. Until the void or air cavities are filled with water, water penetrates to the material through its solid phase. In general, temperature strongly increases the early stages of water rehydration. There is a resistance of crystalline structures to salvation, whereas amorphous regions hydrate faster. The presence of anions in water affects volume increase during water absorption (Rahman and Perera, 1999). 


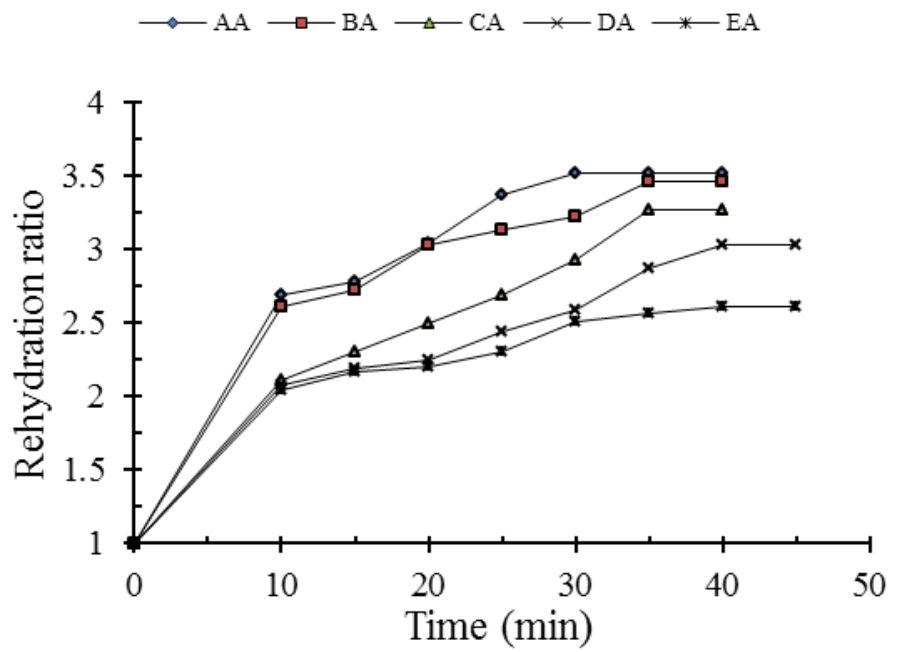

Fig 4. Rehydration characteristic of mashed potato incorporated Masyaura

AA, BA, CA, DA and EA denote Masyaura prepared with 0 (control), 6.25, 12.5, 18.75 and 25 parts mashed potato, respectively.

Water binding capacity varies with protein source, composition and presence of carbohydrates (hydrophilic polysaccharides) lipids, $\mathrm{pH}$ and salts. It may be influenced by previous processing such as heating, alkali processing and disulphide linking (Kinsella, 1976). Water absorption capacity of sunflower meal increased slightly as the solubility decreased with longer mixing time. Other factors which affect water absorption capacity of proteins include amino acid composition, protein conformation (shape, size), surface topography, surface charge and polarity, ionic concentration, $\mathrm{pH}$ and temperature (Kinsella et al, 1985).

\section{Proximate composition of Masyaura}

Masyaura prepared by incorporating 18.75 parts mashed potato was found to be superior in terms of textural and sensory quality. The proximate composition is presented in Table 1.

Table 1: Proximate composition Masyaura incorporated with 18.75 parts of mashed potato

\begin{tabular}{ll}
\hline Proximate constituents & Values* $(\%)$ \\
\hline Moisture content & $10.83(0.53)$ \\
Crude protein & $16.52(1.27)$ \\
Crude fat & $0.33(0.003)$ \\
Total ash & $2.74(0.023)$ \\
Crude fibre & $2.11(0.041)$ \\
Nitrogen free extractives & $67.47(2.18)$ \\
\hline
\end{tabular}

* values are the means of three determinations and figures in the parentheses are their standard deviations.

Lama (1988) reported values for moisture content, crude protein, crude fat, total ash, crude fibre and carbohydrate were $8.2,22,0.44,4.8,5.12$ and $64.5 \%$ respectively for Masyaura prepared with green gram, black gram, chayote and rape leaves. Similarly, moisture, crude protein, crude fat, total ash, crude fibre and carbohydrate content of Masyaura prepared with blackgram and colocasia were reported to be $8.2 \%, 20.6 \%, 0.39 \% 3.8 \%$, $4.2 \%$ and $62.81 \%$ respectively (Deo, 2003). Subedi (1999) reported protein rich Masyaura prepared by partially replacing blackgram with soybean $(20 \%)$ and values for moisture, crude protein, crude fat, total ash, crude fibre and carbohydrate were 8.5, 23.3, 3.5, 4.3, 4.3 and $60.3 \%$ respectively.

\section{Conclusions}

The study concluded that Masyaura prepared by incorporating mashed potato increased the bulk density and disintegration time while rehydration ratio was also decreased in comparison to those prepared only by 
incorporating bengal gram flour and Clocasia. Incorporation of 18.75 part mashed potato in the recipe by replacing the black gram was found to be beneficial for improving bulk density, disintegration time and texture of Masyaura.

\section{References}

Dahal N R, Karki T B, Swamylingappa B, Li Q and Gu G. Traditional foods and beverages of Nepal-a review. Food Reviews Int. 2005, 21, 1-25.

Dahal N R, Rao ER and Swamylingappa B. Biochemical and nutritional evaluation of Masyaura-a legume based traditional savoury of Nepal. J. Food Sci. Technol, 2003, 40 (1), 17-22.

Deo R. Study on the effect of fermentation time and temperature on the quality of Maseura. Unpublished B. Tech. (Food) Thesis.Tribhuvan Univ, Nepal. 2003.

Fellows PJ. Food Processing Technology: Principles and Practice. (2nd Ed).Woodhead Publishing Limited, Cambridge England. 2000.

Gajurel C and Baidya K. Masyaura Technology. In: "Traditional Technology of Nepal ". Tribhuvan Univ. Nepal. (in Nepalese). 1979.

Ikhlas B, Huda N and Noryati I. Chemical composition and physicochemical properties of meatballs prepared from Mechanically Deboned Quail Meat Using Various type of flour.International Journal of poultry Science. 2011, 10 (1), 30-7.

Jansky SH. Potato flavor. In: "Handbook of Fruit and Vegetable Flavors". (Y.H. Hui. Ed.). pp. 935-946. New Jersey. A John Wiley and Sons, Inc. Publication. 2010.

Karki T. Some Nepalese traditional foods and beverages. In: "Traditional Foods, Some Products and Technologies".Mysore, India. Central Food Technological Research Institute. 1986, 84-98.

Kaur S and Aggarwal P. Development and quality characterisctice of nutritionally enhanced potato legume based wari- an Indian traditonal savoury. Journal of Food science \& Technology, 201653(4),1899-908.

Kinsella JE, Damodaran $\mathrm{S}$ and German B. Physicochemical and functional properties of oilseeds with emphasis on soya proteins. In: "New Protein Food -5, Seed Storage Protein". 1985, pp 107-79. London, U.K. Academic press Inc.

Lama JP. Preparatin and quality evaluation of Maseurabased on locally available raw materials. Unpublished B. Tech. (Food) Thesis. Tribhuvan Univ., Nepal. 1988.

Lawless HT and Heymann H.Sensory Evaluation of
Food, Principles and Practices. (2nd ed.). Springer New York Dordrecht Heidelberg London. 2010.

Moran ET. Effect of pellet-quality on the performance of meat birds. In: Recent Advances in Animal Nutrition. (W. Haresign and D.J.A. Cole. Eds.). pp. 87-108. Butterworth, LondonNepal Standard. (2037 BS). Stndard of white bread. Office of the Nepal Standard (Ministry of Industry), Nepal. 1989 pp. 12-3.

Nieto G, Castillo M, Xiong YL, Alvarez D, Payne FA and Garrido M D. Antioxidant and emulsifying properties of alcalase-hydrolyzed potato proteins in meat emulsions with different fat concentrations. Meat Science 2009, 83, 24-30.

Okos MR, Narsimhan G, Singh RK and Weitnauer AC. Food dehydration. In: "Handbook of Food Engineering" (D. R. Heldman and D.B. Lund, Eds.). pp. 437-562. New York. Marcel Dekker Inc. 1992.

Rahman MS and Perera CO. Drying and food preservation. In: "Handbook of Food Preservation". (M.S. Rahman, Ed.). pp. 173-216. New York. Marcel Dekker. 1999.

Ranganna S. Handbook of Quantitative Analysis of Fruit and Vegetable Products. Tata McGraw-Hill Book Publishing Co. New Delhi. 2007

Schwartz JB and Zelinskie JA. The binding and disintegrant properties of the corn starch fraction: amylose and amylopectin. Drug Dev. and Industrial Pharmacy. 1978, 4(51), 463-483. [Cited in M. Thomas, T.V. Vliet, and A.F.B. Poel. (1998). Physical quality of pelleted animal feed 3 . Contribution of feedstuff components.Animal Feed Sci. Technol. 70, 59-78]

Subba D. Preparation and study of Masyaura-A traditional product. Unpublished B. Tech. (Food) Thesis. Tribhuvan Univ, Nepal. 1985.

Subedi C. Formulation and preparation of protein rich Maseura. Unpublished B. Tech. (Food) Thesis. Tribhuvan Univ, Nepal. 1999.

Tamang JP. Himalayan Fermented Foods: Microbiology, Nutrition, and Ethnic Values. CRC Press. USA. 2010.

Tamang J P and Kailasapathy K. Fermented Foods and Beverages of the World. CRC Press. USA. 2010. 